\title{
KNOWLEDGE MANAGEMENT AND ENTERPRISE RESOURCE PLANNING IMPLEMENTATION: A CONCEPTUAL MODEL
}

\author{
Sevenpri Candra
}

School of Business Management, Bina Nusantara University, Jakarta, Indonesia

Received 2013-06-03; Revised 2013-07-09; Accepted 2013-11-30

\begin{abstract}
The purpose of this research is examining the influence of organizational learning and knowledge management in enterprise resource planning implementation. This study is based on organizational learning, knowledge management and enterprise resource planning implementation. This research did not test all organizational factors and focus particularly on knowledge management capacity and absorptive capability. Enterprise resource planning implementation successful is a must. In today's global and competitor in business, enterprise resource planning is becoming one of the main tools to achieve competitiveness in business. Enterprise resource planning is an infrastructure to create and maintain business to improve frontoffice and back-office efficiency and effectiveness. This study is significant to bring new thinking in determines the key antecedents to successful enterprise resource planning implementation based on knowledge management perspectives and it will helps to understand the key success factor in enterprise resource planning implementation.
\end{abstract}

Keywords: Organizational Learning, Knowledge-Based View, Enterprise Resource Planning, Innovation and Culture

\section{INTRODUCTION}

In contemporary times, technology has become an important part from business activity. Technology became an important part in a business strategy. Technology is expected to make a process of the business become more efficient and effective. One of these technologies is Enterprise Resource Planning (ERP) or Enterprise System. ERP is a collection of software that has been integrated into one package for an organization's business processes to become more effective and efficient. ERP covers to manufacturing, supply chain, sales, financial, human resources, budgeting and customer service activity.

According to Turban et al. (2006), ERP or enterprise systems control all major business processes with single software architecture in real time. It is comprised of a set of applications that automate routine back-end operations such as financial management, inventory management, scheduling, order fulfillment, cost control, accounts payable and receivable, It includes front-end operations such as POS, Field Sales, Service. It also increases efficiency, improves quality, productivity and profitability.

ERP have emerged as possibly the most important and challenging development in the corporate use of Information Technology (IT). Organizations like corporation have invested heavily in these large, integrated application software suites expecting improvements in business process, management expenditure, customer service and more generally, competitiveness (Sedera and Gable, 2010). The core idea in developing ERP system was catching up to the real meaning of "integration" (Mehrjerdi, 2010).

Based on Barney and Clark (2007), in ResourceBased Theory (RBT), it is determined that resources can be the sources of competitive advantage if they have the characteristics of value, rarity, inimitability and non- 
substitutability. Despite the widely held belief that Information Technology (IT) is fundamental to a firm's survival and growth, scholars are struggling to specify the underlying mechanisms linking IT to financial performance. Evidence in real life business and case studies indicate that effective and efficient use of IT is a key factor differentiating successful firms from their less successful counterparts (Bharadwaj, 2000). Resourcebased theorists contend that physical assets, in and of themselves, can serve as sources of competitive advantage only if they "outperform" equivalent assets of competitors (Barney, 1991).

IT also can be as a source of sustained competitive advantage. RBT and IT are believed to be possible role in creating sustained competitive advantages for the firms (Barney and Clark, 2007; Wade and Hulland, 2004). This belief based on two assertions underlying resources based theory, first this resource can be different in firm different and second this differences resource can be long lasting. Using $\mathrm{RBV}$, this research will specifically investigate the relationship organizational learning and knowledge management with successful ERP Implementation Table 1.

The purpose of this research is examining the influence of organizational learning and knowledge management on enterprise resource planning implementation. These research main points are conceptualizing the role of organizational learning and knowledge management in Enterprise Resource Planning Implementation Table 2.

\section{LITERATURE REVIEW}

This section is constructed to explain the views and/or the theories to be used as theoretical foundations of this research are threefold Resource-Based Theory (RBT), Knowledge-Based View (KBV) and Organizational Learning (OL). Beside views or theories that will be reviewed, also there are several research studies that related with Enterprise Resource Planning (ERP) and Corporate Culture that believe as factor that influence ERP Implementation Success.

Table 1. Research in ERP area

\begin{tabular}{llll}
\hline Representative study & Focus of research & Statistical evidence & Location \\
\hline $\begin{array}{l}\text { Pan } \text { et al. } \text { (2001); O'Leary (2002); } \\
\text { Newell } \text { et al. (2003); }\end{array}$ & Knowledge management & No & Multiple \\
$\begin{array}{l}\text { Ko } \text { et al. } \text { (2005); Jones } \text { et al. (2006); } \\
\text { Newell } \text { et al. (2006); Pan } \text { et al. (2007); }\end{array}$ & & \\
McGinnis and Huang (2007) & & & \\
Wang et al.(2007) & Knowledge management & Yes & Taiwan \\
Sedera and Gable (2010) & Knowledge management & Yes & Australia \\
Park et al. (2007) & Organizational learning & Yes & Korea \\
Present study & Knowledge Management & Yes & Indonesia \\
& and organizational learning & & \\
\hline
\end{tabular}

Table 2. Gaps in number of internationally published research

\begin{tabular}{|c|c|c|c|c|c|c|c|}
\hline Topic & 2005 & 2006 & 2007 & 2008 & 2009 & 2010 & 2011 \\
\hline $\begin{array}{l}\text { Knowledge management and } \\
\text { organizational learning }\end{array}$ & 10 & 13 & 10 & 13 & 15 & 23 & 7 \\
\hline $\begin{array}{l}\text { Knowledge management and } \\
\text { organizational learning }\end{array}$ & 1 & 2 & 0 & 3 & 5 & 4 & 1 \\
\hline $\begin{array}{l}\text { Knowledge management and } \\
\text { enterprise resource planning }\end{array}$ & 1 & 0 & 1 & 2 & 0 & 0 & 2 \\
\hline $\begin{array}{l}\text { Absorptive capacity and } \\
\text { knowledge management }\end{array}$ & 2 & 3 & 1 & 4 & 1 & 3 & 6 \\
\hline $\begin{array}{l}\text { Organizational learning and } \\
\text { enterprise resource planning }\end{array}$ & 0 & 1 & 1 & 0 & 0 & 0 & 0 \\
\hline $\begin{array}{l}\text { Knowledge management and } \\
\text { organizational learning } \\
\text { and enterprise resource planning }\end{array}$ & 0 & 0 & 0 & 0 & 0 & 0 & 0 \\
\hline
\end{tabular}

Source: Search from www.proquest.com and www.sciencedirect.com on May 2, 2011 


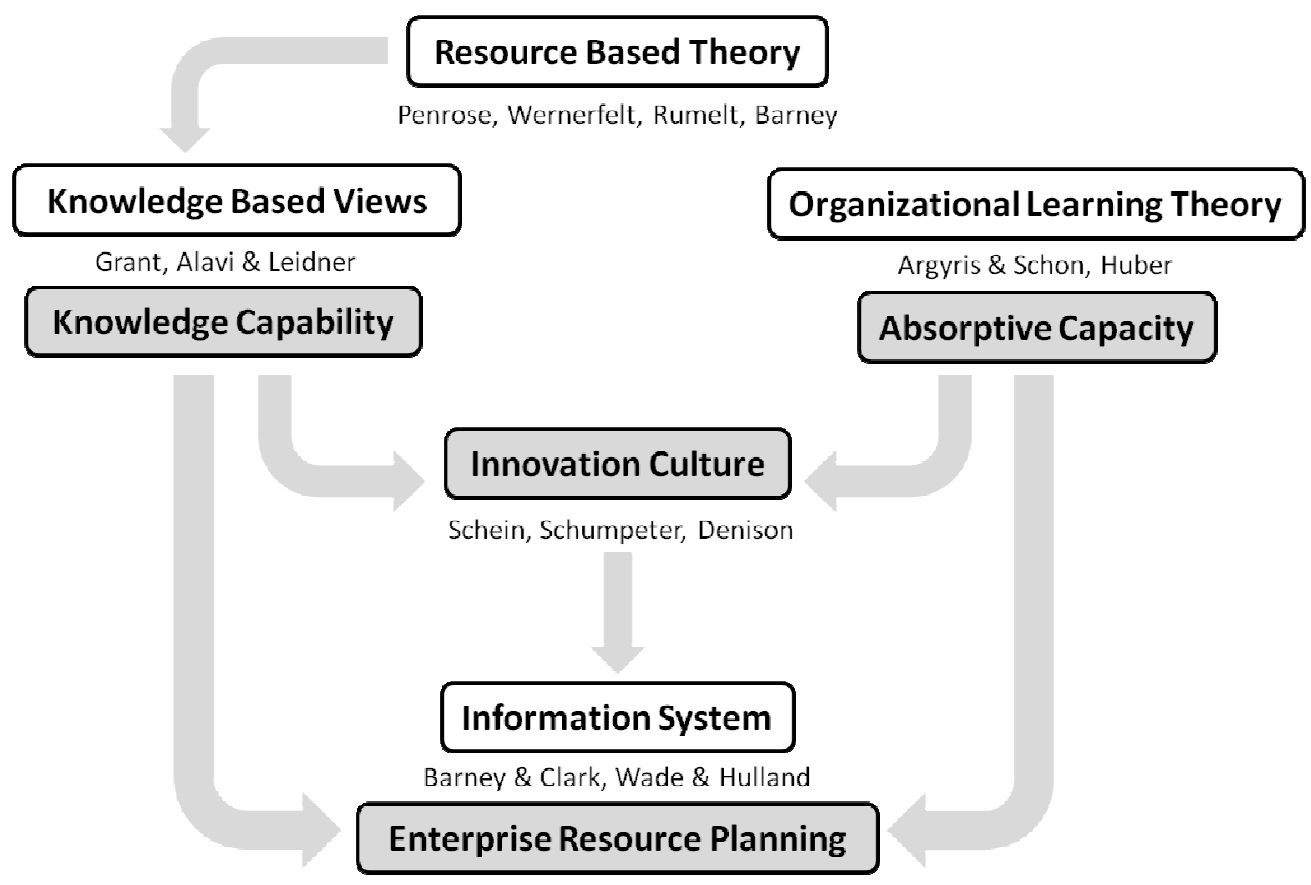

Fig. 1. Theoretical foundations of the theories/views

In general, the flow of views and/or theories as theoretical foundations of this research is described in Fig. 1 below.

\subsection{ERP and ERP Implementation Success}

ERP systems can be regarded as one of the most innovative developments in Information Technology (IT) of the 1990s. With growing interest of many organizations in moving from functional to processbased IT infrastructure, ERP systems have become one of today's most widespread IT solutions (Al-Mashari, 2003). Enterprise systems are clearly a phenomenon in the IT marketplace. Their potential significance for computer-using organizations cannot be overstated. They represent a nearly complete re architecting of an organization's portfolio of transactions processing applications systems to achieve integration of business processes, systems and information-along with corresponding changes in the supporting computing platform (hardware, software, databases and telecommunications) (Markus and Tanis, 2000).

ERP encompasses a wide range of software products supporting day-to-day business operations and decisionmaking. ERP systems serve many industries and functional areas in an integrated fashion, attempting to automate operations from the supply chain management, inventory control, manufacturing scheduling, sales support, customer relationship management, financial and cost accounting, human resources and many other functional areas in an organization (Sedera et al., 2003).

According to Markus and Tanis (2000) Enterprise systems have several characteristics, each with important implications for the organizations that adopt them. Integration, Enterprise systems promise seamless integration of all the information following through a company-financial and accounting information, human resource information, supply chain information and customer information. Packages, Enterprise systems are commercial packages; that is, they are purchased or leased from software vendors rather than being developed in-house from scratch. Best Practices, because they are designed to fit the needs of many organizations, enterprise systems are built to support generic business processes that may differ quite substantially from the way any particular organization does business.

Implementation of ERP is a complex process, deals with many conditions and factors that will be influence every aspect of implementation. These conditions can have positive and also negative outcome to the implementation. The results of some recent studies related to ERP implementation success factors will be describe following this review. 
According to Bhatti (2005) implementing an ERP system project is a difficult and high cost proposition as it places tremendous demands on an organization's time and resources. Based on a survey of 53 organizations in Australia, the results suggest that a 65 item instrument that measures seven dimensions of ERP implementation is well-validated. Bhatti (2005) suggested several factors that influenced the success of ERP: Project management, process redesign, user training, technological infrastructure, change management, risk management, top management support, communication, team work, user involvement, use of consultant, clear goals and objectives and for the success outcome, there are two measure, project outcome and business outcome.

In another research Nah et al. (2001) investigated success factors for ERP implementation by conducting a literature review. According to their research, there are several factors that influence success factor of ERP implementation. These factors are teamwork, change management, top management support, plan and vision, business process management and development, project management, monitoring, effective communication, software development and testing, the role of the project champion and appropriate business and IT legacy systems.

Zabjek et al. (2009) also pointed out several factors critical to ERP implementation. These factors are top management support, clear goals and objective, project team organization and competence, user training and education, business process engineering, change management, communication, user involvement and participation, legacy system management, consulting services, project management, sponsorship, system, technological and minimal customization. These factors have a positive impact on successful ERP implementation and should be treated as very important in ERP systems implementation projects. The results also support the importance of top management perception: If they consider business process management as a basis of business change, this contributes to a strong and positive influence on successful ERP implementation. Recent study by Supramaniam and Kuppusamy (2010) highlighted several factors such as top management support, clear goals and objectives, user training on software and education on new business processes.

\subsection{Resource-Based Theory (RBT)}

RBT rooted from resource-based view that emerged in the 1980s partly in reaction to the perceived external environment-bias of the dominant competitive strategy paradigm. RBT is one of the frameworks in the strategic management literatures (Newbert, 2007). Based on Wernerfelt (1984), for the firm, resources and products are two sides of the same coin. Most products require the services of several resources and most resources can be used in several products. By specifying the size of the firm's activity in different product markets, it is possible to infer the minimum necessary resource commitments. Conversely, by specifying a resource profile for a firm, it is possible to find the optimal product-market activities.

That same year, Rumelt (1991) published a second resource-based paper in a book of readings coming out of a conference on strategic management. While these papers addressed similar kinds of issues, they did not refer to each other. Where Wernerfelt (1984) focused on establishing the possibility that a theory of firm performance differences could be developed in terms of the resources that a firm controls, Rumelt began describing a strategic theory of the firm, that is, a theory explaining why firms exist, that focused on the ability of firms to generate economic rents (Freeman et al., 2001).

Barney (1986) introduces the concept of strategic factor markets as the market where firms acquire or develop the resources they need to implement their product market strategies. While this influential body of research within the field of strategic management was named by Wernerfelt (1984) in his article A ResourceBased Theory of the Firm, the origins of the resourcebased theory can be traced back to earlier research. Retrospectively, elements can be found in works by Coase (1937); Stigler (1961) and Chandler (1977), where emphasis is put on the importance of resources and its implications for firm performance (Mahoney and Pandian, 1992; Rugman and Verbeke, 2002).

\subsection{Knowledge-Based View (KBV)}

The objectives of KBV are to make the enterprise act as intelligently as possible to secure its viability and overall success and to otherwise realize the best value of its knowledge assets (Grant, 1996). In other words, knowledge is the most strategically important resource of the firm. Its proponents argue that because knowledgebased resources are usually difficult to imitate and socially complex, heterogeneous knowledge bases and capabilities among firms are the major determinants of sustained competitive advantage and superior corporate performance.

This knowledge is embedded and carried through multiple entities including organizational culture and identity, policies, routines, documents, systems and employees. Originating from the strategic management literature, this perspective builds upon and extends the Resource-Based View of the firm (RBV) initially promoted by Penrose (1995) and later expanded by others (Wernerfelt, 1984; Barney, 1991; Conner, 1991). 
Information technologies can play an important role in the knowledge-based view of the firm in that information systems can be used to synthesize, enhance and expedite large-scale intra- and inter-firm knowledge management (Alavi and Leidner, 2001).

\subsection{Organizational Learning Theory}

The basic assumption in most organizational learning theory is that learning is socially constructed, that is, what is learned and how learning occurs are fundamentally connected to the context in which that learning occurs (Lane et al., 2001). Argyris and Schon (1978) defines organizational learning as the process of "detection and correction of errors". In their view organizations learn through individuals acting as agents for them: "The individuals' learning activities, in turn, are facilitated or inhibited by an ecological system of factors that may be called an organizational learning system".

One key aspect of organizational learning to remember is that an organization should not lose out on its learning abilities when members of the organization leave. The concept of organizational memory means that effective learning organizations should not only influence the current members, but also future members due to the experiences, beliefs and norms that are accumulated along the way. Creating a learning organization is only half the solution to a challenging problem (Prahalad and Hamel, 1990). Equally important is unlearning some of the past that has not moved the company forward on a path of healthy growth.

Huber (1991) considers four constructs as integrally linked to organizational learning: Knowledge acquisition, information distribution, information interpretation and organizational memory. He clarifies that learning need not be conscious or intentional. Further, learning does not always increase the learner's effectiveness, or even potential effectiveness. Moreover, learning need not result in observable changes in behavior. Taking a behavioral perspective, Huber (1991) notes: An entity learns if, through its processing of information, the range of its potential behaviors is changed.

Argyris and Schon (1978) suggest that there are "deeper" reasons behind the implementation gap of Information System, especially when the technology was used to deal with the more complex and ill-structured problems faced by the organization. They suggest that the information systems need to be viewed as a part of a more general problem of Organizational Learning.

\subsection{Innovation and Culture}

The term innovation derives from the Latin innovatio, the noun of action from innovare. The word first came into modern use in 1540 and stems from the Latin innovatus, pp. of innovare "to renew or change," from in- "into" + novus "new". Although the term is broadly used, innovation generally refers to the creation or improvement of products, technologies, or ideas. Innovation is distinguished from renovation in that innovation generally signifies a substantial change or difference versus more incremental changes.

Innovation has been recognized as a key element of dynamic efficiency and competition of markets since the work of Schumpeter (1934). Following Schumpeter (1934), contributors to the scholarly literature on innovation typically distinguish between invention, an idea made manifest and innovation, ideas applied successfully in practice. In economics the change must increase value, customer value, or producer value. The goal of innovation is positive change, to make someone or something better.

A key component in the success of industrial firms is the extent of their innovativeness. Innovativeness relates to the firm's capacity to engage in innovation; that is, the introduction of new processes, products, or ideas in the organization (Hult et al., 2004). The current situation of the environment (e.g., uncertainty, high risk and volatility) involves that firms need develop innovations in order to maintain or increase their competitiveness. The capacity to innovate is among the most important factors that impact business performance (Hurley and Hult, 1998). Successful organizations have the capacity to absorb innovation into the organizational culture and management processes of the organization (Syrett and Lammiman, 1997; O'Reilly and Tushman, 2002). According to (O'Reilly and Tushman, 2002), organization culture lies at the heart of innovation.

Tylor (1871) provides one of the earliest definitions of culture: "the complex whole which includes knowledge, belief, art, morals, custom and any other capabilities and habit acquired by man as a member of society". According to Schein (2009) organizational culture as a pattern of basic assumptions-invented, discovered or developed by a given group as it learns to cope with its problems of external adaptation and internal integration. Such a pattern has worked well enough to be considered valuable and, therefore, to be taught to new members as the correct way to perceive, think and feel in relation to those problems.

\section{RESEARCH MODEL}

This is a proposed research model to seek the role of knowledge management in ERP implementation success. 


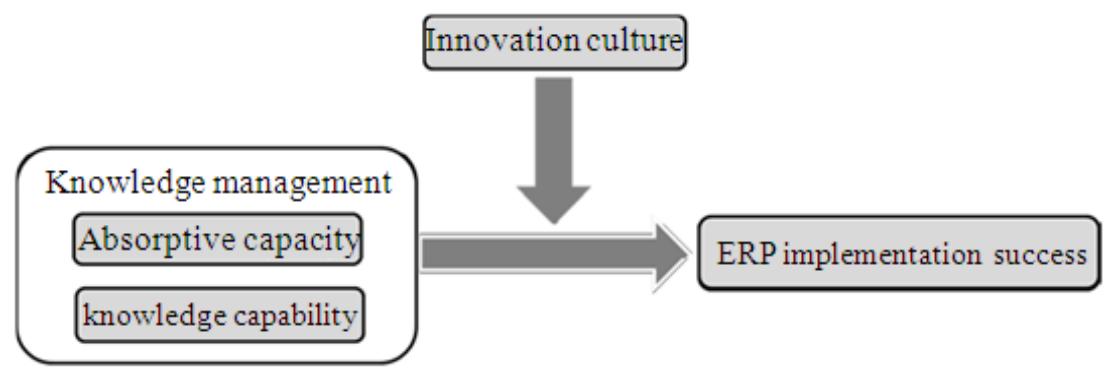

Fig. 2. Proposed research model

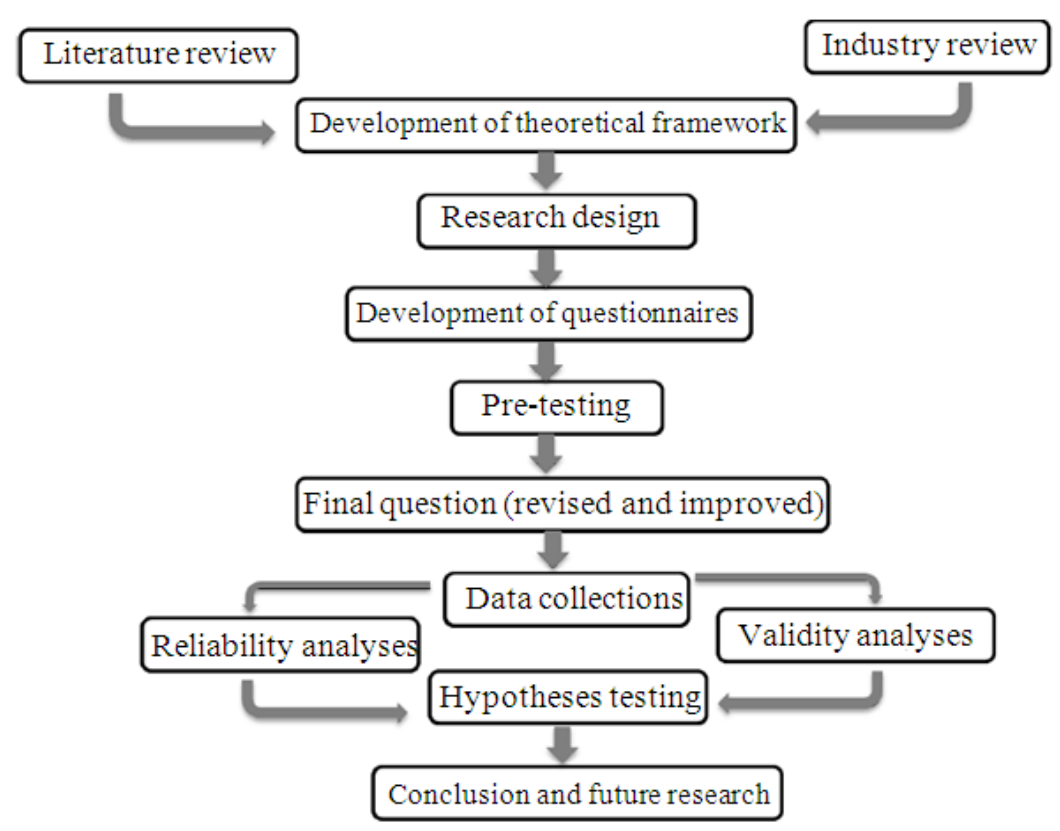

Fig. 3. Research process and plan

Table 3. Construct of variables

\begin{tabular}{|c|c|c|c|}
\hline & Variables & Dimensions & References \\
\hline $\begin{array}{l}\text { Organizational } \\
\text { learning }\end{array}$ & Absorptive capacity & $\begin{array}{l}\text { Acquisition } \\
\text { assimilation } \\
\text { transformation } \\
\text { exploitation }\end{array}$ & $\begin{array}{l}\text { Crossan et al. (1999); } \\
\text { Huber (1991); Alavi and Leidner (2001); } \\
\text { Jimenez-Barrionuevo et al. (2011); } \\
\text { Lane } \text { et al. (2001) }\end{array}$ \\
\hline $\begin{array}{l}\text { Knowledge } \\
\text { based views }\end{array}$ & knowledge capability & $\begin{array}{l}\text { Knowledge creation } \\
\text { knowledge retention } \\
\text { knowledge transfer } \\
\text { knowledge application }\end{array}$ & $\begin{array}{l}\text { Gable et al. }(2008) \\
\text { Grant (1996); Pan } \text { et al. }(2001) \text {; } \\
\text { Alavi and Leidner (2001); } \\
\text { Tanriverdi (2005) }\end{array}$ \\
\hline Culture & innovation culture & $\begin{array}{l}\text { Innovation intention } \\
\text { innovation infrastructure } \\
\text { innovation influence } \\
\text { innovation implementation }\end{array}$ & $\begin{array}{l}\text { Dobni (2006); Hult et al. (2004) } \\
\text { Hurley and Hult (1998) } \\
\text { Skerlavaj et al. (2010) }\end{array}$ \\
\hline ERP & $\begin{array}{l}\text { ERP implementation } \\
\text { successful }\end{array}$ & $\begin{array}{l}\text { System quality } \\
\text { Information quality } \\
\text { Individual impact } \\
\text { organization impact }\end{array}$ & $\begin{array}{l}\text { Gable } \text { et al. }(2008) ; \\
\text { Petter } \text { et al. }(2008) ; \\
\text { Lee } \text { et al. }(2007) ; \\
\text { Beshnahan }(1996) ;\end{array}$ \\
\hline
\end{tabular}


As seen on Fig. 2. The research model is based on OL and KBV. Absorptive capacity will be variable in organizational learning; the dimensions are acquisition, assimilation, transformation, exploitation (Crossan et al., 1999; Huber, 1991; Alavi and Leidner, 2001; Lane et al., 2001). Dimension for knowledge capability are knowledge creation, knowledge retention, knowledge transfer, knowledge application (Gable et al., 2008; Grant, 1996; Alavi and Leidner, 2001; Tanriverdi, 2005). Dimensions for innovation culture are innovation intention, innovation infrastructure, innovation influence, innovation implementation Table 3 (Dobni, 2006; Hult et al., 2004; Hurley and Hult, 1998; Skerlavaj et al., 2010).

\section{RESEARCH DESIGN}

The flow of thinking framework will be developed from literature and industry review as constructed in this research methodology to ensure that the research design, plan and execution of this research can be implemented as planned and scheduled. Furthermore, the research methodology is formulated in order that the objectives of the research can be achieved. Basically, scientific research is divided into two categories applied and basic research, as refer to code of ethics and specific social behavior norms. This research is categorized as an applied research, to be designed based on in-depth review of literatures, empirical research concept and understanding about research object. The process and work-plan of this research are designed systematically, started from literature and industry reviews and ended with the setup of completed report of dissertation. In general, the process and work plan of this research are described in Fig. 3.

\section{CONCLUSION}

This study is significant to bring new thinking in determines the key antecedents to successful enterprise resource planning implementation based on knowledge management perspectives and it will helps to understand the key success factor in enterprise resource planning implementation. Future research could assess the influence of organizational and knowledge on enterprise resource planning implementation success with more indepth dimension and measurement items.

Enterprise resource planning implementation successful is a must. In today's global business and competitor in business, enterprise resource planning is becoming one of the main tools to achieve competitiveness in business environment. Enterprise resource planning is an infrastructure to create and maintain business to improve front-office and backoffice efficiency and effectiveness. A better understanding of the factors affecting the success of ERP Implementation will benefit practitioners who implement these systems. Organization from small through enterprise that currently beginning or planning ERP Implementations, will benefits from this knowledge.

Future research could assess the influence of organizational and knowledge on enterprise resource planning implementation success with more in-depth dimension and measurement items. Enterprise resource planning implementation successful is a must.

\section{REFERENCES}

Alavi, M. and D.E. Leidner, 2001. Review: Knowledge management and knowledge management systems: Conceptual foundations and research issues. MIS Q., 25: 107-136.

Al-Mashari, M., 2003. Enterprise resource planning (ERP) systems: A research agenda. Indus. Manage. Data Syst., 103: 22-27. DOI: 10.1108/02635570310456869

Argyris, C. and D.A. Schon, 1978. Organizational Learning: A Theory of Action Perspective. 1st Edn., Addison Wesley, Reading, ISBN-10: 0201001748, pp: 356.

Barney, J.B. and D.N. Clark, 2007. Resource-Based Theory: Creating and Sustaining Competitive Advantage. 1st Edn., Oxford University Press, New York, ISBN-10: 0199277680, pp: 316.

Barney, J.B., 1986. Strategic factor markets: Expectations, luck and business strategy. Manage. Sci.

Barney, J.B., 1991. Firm resources and sustained competitive advantage. J. Manage., 17: 99-120.

Beshnahan, J., 1996. Mixed messages. CIO Mag., 9: 7478.

Bharadwaj, A.S., 2000. A Resource-based perspective on Information technology capability and firm performance: An empirical investigation. MIS Q., 24: $169-196$.

Bhatti, T.R., 2005. Critical Succss factors for the implementation of Enterprise Resource Planning (ERP): Empirical validation. Proceedings of the Second International Conference on Innovation in Information Technology, (IIT'05).

Chandler, A.D., 1977. The Visible Hand: The Managerial Revolution in American Business. 1st Edn., Harvard University Press, Cambridge, Mass., ISBN-10: 0674940520, pp: 608. 
Coase, R.H., 1937. The nature of the firm. Economica, 4: 386-405. DOI: 10.1111/j.1468-0335.1937.tb00002.x

Conner, K.R., 1991. A historical comparison of resourcebased theory and five schools of thought within industrial organization economics: Do we have a new theory of the firm? J. Manage., 17: 121-154. DOI: $10.1177 / 014920639101700109$

Crossan, M.M., H.W. Lane and R.E. White, 1999. An organizational learning framework: From intuition to institution. Acad. Manage. Rev., 24: 522-537. DOI: 10.5465/AMR.1999.2202135

Dobni, C.B., 2006. The innovation blueprint. Bus. Horizons, 49: 329-339. DOI: 10.1016/j.bushor.2005.12.001

Freeman, R.E., J.S. Harrison and M.A. Hit, 2001. The Blackwell Handbook of Strategic Management. 1st Edn., Blackwell Publishers, ISBN-10: 0631218602.

Gable, G.G., D. Sedera and T. Chan, 2008. Reconceptualizing information system success: The ISImpact measurement model. J. Assoc. Inform. Syst., 9: 377-408.

Grant, R.M., 1996. Toward a knowledge-based theory of the firm. Strategic Manage. J., 17: 109-122.

Huber, G.P., 1991. Organizational learning: The Contributing processes and the literatures. Organ. Sci., 2: 88-115. DOI: $10.1287 /$ orsc. 2.1 .88

Hult, G.T., R.F. Hurley and G.A. Knight, 2004. Innovativeness: Its antecedents and impact on business performance. Indust. Market. Manage., 33: 429-438. DOI: 10.1016/j.indmarman.2003.08.015

Hurley, R.F. and G.T.M. Hult, 1998. Innovation, market orientation organizational learning: An integration and empirical examination. J. Market., 62: 42-54.

Jimenez-Barrionuevo, M.M., V.J. Garcia-Morales and L.M. Molina, 2011. Validation of an instrument to measure absorptive capacity. Technovation, 31: 190202. DOI: 10.1016/j.technovation.2010.12.002

Jones, P.D., D.E. Parker, T.J. Osborn and K.R. Briffa, 2006. Global and hemispheric temperature anomalies-land and marine instrumental records. University of East Anglia.

Ko, M.A., C.O. Rosario, J.W. Hudson, S. Kulkarni and A. Pollett et al., 2005. Plk4 haploinsufficiency causes mitotic infidelity and carcinogenesis. Nat. Genet., 37: 883-888. PMID: 16025114

Lane, P.J., J.E. Salk and M.A. Lyles, 2001. Absorptive capacity, learning and performance in international joint ventures. Strategic Manage. J., 22: 1139-1161. DOI: $10.1002 / \mathrm{smj} .206$
Lee, W., D. Tillo, N. Bray, R.H. Morse and R.W. Davis et al., 2007. A high-resolution atlas of nucleosome occupancy in yeast. Nat. Genet., 39: 1235-1244. PMID: 17873876

Mahoney, J.T. and J.R. Pandian, 1992. The resourcebased view within the conversation of strategic management. Strategic Manage. J., 13: 363-380. DOI: $10.1002 / \mathrm{smj} .4250130505$

Markus, M. and C. Tanis, 2000. The Enterprise Systems Experience-From Adoption to Success. In: Framing the Domains of IT Management: Projecting the Future...Through the Past, Zmud, R.W. (Ed.), Pinnaflex Educational Resources Inc., ISBN-10: 1893673065.

McGinnis, T.C. and Z. Huang, 2007. Inform. Manage., 44: 626-634. DOI: 10.1016/j.im.2007.05.006

Mehrjerdi, Y.Z., 2010. Enterprise resource planning: Risk and benefit analysis. Bus. Strategy Series, 11: 308-324. DOI: 10.1108/17515631011080722

Nah, F.F.H., J.L.S. Lau and J. Kuang, 2001. Critical factors for successful implementation of enterprise systems. Bus. Process Manage. J., 7: 285-296. DOI: 10.1108/14637150110392782

Newbert, S.L., 2007. Empirical research on the resourcebased view of the firm: An assessment and suggestions for future research. Strategic Manage. J., 28: 121-146. DOI: 10.1002/smj.573

Newell, C.A., I. Birch-Machin, J.M. Hibberd and J.C. Gray, 2003. Expression of green fluorescent protein from bacterial and plastid promoters in Tobacco chloroplasts. Transgenic Res., 12: 631-634. DOI: 10.1023/A:1025812309254

Newell, K.A., C. Deng and X.F. Huang, 2006. Increased cannabinoid receptor density in the posterior cingulate cortex in schizophrenia. Exp. Brain Res., 172: 556-560. DOI: 10.1007/s00221-006-0503-x

O'Leary, T., 2002. Foucault and the Art of Ethics. 1st Edn., Bloomsbury Academic, London, ISBN-10: 0826456278,pp: 212.

O'Reilly, C.A. and M.L. Tushman, 2002. Winning through Innovation: A Practical Guide to Leading Organizational Change and Renewal. 1st Edn., Harvard Business Press, Boston, MA., ISBN-10: 1578518210, pp: 272.

Pan, H., J.B. Yi, L. Shen, R.Q. Wu and J.H. Yang et al., 2007. Room-Temperature Ferromagnetism in Carbon-Doped ZnO. Phys. Rev. Lett., 99: 127201127207. DOI: 10.1103/PhysRevLett.99.127201

Pan, Z.W., Z.R. Dai and Z.L. Wang, 2001. Nanobelts of semiconducting oxides. Science, 291: 1947-1949. DOI: $10.1126 /$ science. 1058120 
Park, S.W., E. Kaimoyo, D. Kumar, S. Mosher and D.F. Klessig, 2007. Methyl salicylate is a critical mobile signal for plant systemic acquired resistance. Science, 318: 113-116. DOI: 10.1126/science. 1147113

Penrose, E.T., 1995. The Theory of the Growth of the Firm. 1st Edn., Oxford University Press, ISBN-10: 0198289774, pp: 272.

Petter, S., W. DeLone and E. McLean, 2008. Measuring information systems success: Models, dimensions, measures and interrelationships. Eur. J. Inform. Syst., 17: 236-263. DOI: 10.1057/ejis.2008.15

Prahalad, C.K. and G. Hamel, 1990. The core competence of the corporation. Harvard Bus. Rev., 68: 71-91.

Rugman, A.M. and A. Verbeke, 2002. Edith Penrose's contribution to the resource-based view of strategic management. Strategic Manage. J., 23: 769-780. DOI: $10.1002 / \mathrm{smj} .240$

Rumelt, R.P., 1991. How much does industry matter? Strategic Manage. J., 12: 167-185. DOI: 10.1002/smj.4250120302

Schein, E.H., 2009. The Corporate Culture Survival Guide. 1st Edn., Jossey-Bass, ISBN-10: 0470293713, pp: 256.

Schumpeter, J.A., 1934. The Theory of Economic Development: An Inquiry into Profits, Capital, Credit, Interest and the Business Cycle. 1st Edn., Transaction Publishers, Piscataway, ISBN-10: 0878556982, pp: 255.

Sedera, D. and G.G. Gable, 2010. Knowledge management competence for enterprise system success. J. Strat. Inform. Syst., 19: 296-306.

Sedera, D., G. Gable and T. Chan, 2003. Knowledge management for ERP success. Proceedings of the 7th Pacific Asia Conference on Information Systems, Jul. 10-13, Adelaide, South Australia, pp: 1405-1420.

Skerlavaj, M., J.H. Song and Y. Lee, 2010. Organizational learning culture, innovative culture and innovations in South Korean firms. Expert Syst. Applic., 37: 6390-6403. DOI: 10.1016/j.eswa.2010.02.080
Stigler, G.J., 1961. The economics of information. J. Political Econ., 69: 213-225.

Supramaniam, M. and M. Kuppusamy, 2010. ERP system implementation: A Malaysian perspective. J. Inform. Technol. Manage., 11: 35-48.

Syrett, M. and J. Lammiman, 1997. The art of conjuring ideas. Director, 50: 48-54.

Tanriverdi, H., 2005. Information technology relatedness, knowledge management capability and performance of multibusiness firms. MIS Q., 29: 311-334.

Turban, E., E.R. McLean and J.C. Wetherbe, 2006. Information Technology for Management: Transforming Organizations in the Digital Economy. 14th Edn., John Wiley Sons, Inc. New Delhi, ISBN-10: 8126509538, pp: 784.

Tylor, E.B., 1871. Primitive Culture: Researches into the Development of Mythology, Philosophy, Religion, Art and Custom. 2nd Edn., John Murray, London.

Wade, M. and J. Hulland, 2004. Review: The resourcebased view and information systems research: Review, extension and suggestions for future research. MIS Q., 28: 107-142.

Wang, M., M. Wu and H. Huo, 2007. Life-cycle energy and greenhouse gas emission impacts of different corn ethanol plant types. Environ. Res. Lett., 2: 024001-024001. DOI: $10.1088 / 1748$ 9326/2/2/024001

Wernerfelt, B., 1984. A resource-based view of the firm. Strategic Manage. J., 5: 171-180. DOI: 10.1002/smj.4250050207

Zabjek, D., A. Kovacic and M.I. Stemberger, 2009. The influence of business process management and some other CSFs on successful ERP implementation. Bus. Process Manage. J., 15: 588-608. DOI: $10.1108 / 14637150910975552$ 